\title{
NOTE
}

\section{Effects of Gonadal Hormones on Hyaluronic Acid Content in Male Mouse Skin}

\author{
Yukio USUI*, Yusuke KANKE**, AND Yo MORI \\ Department of Biochemistry, Tokyo College of Pharmacy, \\ Hachioji-shi, Tokyo 192-O3, Japan
}

\begin{abstract}
Synopsis
Male mice were subcutaneously injected with several gonadal hormones daily for 5 days in order to study their effects on hyaluronic acid (HA) content in the skin.

Increases in both total hexosamine and HA contents were in the following order: estradiol-17 $\beta(10 \mu \mathrm{g})>$ estradiol- $17 \alpha(100 \mu \mathrm{g})>$ estradiol- $17 \alpha(10 \mu \mathrm{g})>$ testosterone $(100 \mu \mathrm{g})$ $>$ control $(\mathrm{p}<0.001)$. No significant differences were noted between $5 \alpha$-dihydrotestosterone $(100 \mu \mathrm{g})$ and control. Testosterone $(100 \mu \mathrm{g})$ or $5 \alpha$-dihydrotestosterone $(100 \mu \mathrm{g})$ injected with estradiol-17 $\beta(10 \mu \mathrm{g})$ blocked the increase in HA content produced by estradiol-17 $\beta$ alone.

Thus, it can be suggested that an increase in HA is not specific for estradiol-17 $\beta$ and that the action of testosterone or $5 \alpha$-dihydrotestosterone is antagonistic to that of estradiol-17 $\beta$ in the male mouse skin.
\end{abstract}

Estradiol-17 $\beta\left(E_{2}-17 \beta\right)$ has been found to cause a marked increase in HA content in the male mouse skin (Sobel et al., 1965), but the mechanism has not been unraveled in contrast to that of other actions of estrogen. In the present work, as part of our continued interest in the mechanism of the skin $\mathrm{HA}$ increase by $\mathrm{E}_{2}-17 \beta$ (Kanke et al., 1977), we have attempted to study the effects of estrogen and androgen, alone and in combination, on the HA content in the male mouse.

Received August 26, 1976.

Present address :

* Department of Microbiology, St. Marianna University School of Medicine, Kawasaki-shi, Kanagawa-ken 213.

** Department of Nutrition, Tokyo University of Agriculture, Setagaya-ku, Tokyo 156.

Abbreviations used are: DHT, $5 \alpha$-dihydrotestosterone; $\mathrm{E}_{2}-17 \alpha$, estradiol-17 $\alpha ; \mathrm{E}_{2}-17 \beta$, estradiol- $17 \beta$; GAG, glycosaminoglycan; HA, hyaluronic acid; $\mathrm{T}$, testosterone.

\section{Materials and Methods}

Estradiol-17 $\alpha$ ( $\beta$ isomer-free) was purchased from Sigma Chemical Co. Ltd. (St. Louis, Mo., U.S.A.). Testosterone propionate was obtained from Tokyo Kasei Kogyo Co. Ltd. (Tokyo, Japan). Estradiol-17 $\beta$ benzoate and $5 \alpha$-dihydrotestosterone were generous gifts from Teikoku Hormone Co. Ltd. (Tokyo, Japan). Hyaluronidase (pure grade) from Streptomyces hyalurolyticus was obtained from Seikagaku Kogyo Co. Ltd. (Tokyo, Japan). Pronase E was purchased from Kaken Co. Ltd. (Tokyo, Japan).

Male mice of the dd/Y strain (20-25 g) were fed with standard laboratory pellets and tap water ad libitum throughout the experiment. The animals were divided into 8 groups and received the hormone tested subcutaneously in $0.1 \mathrm{~m} l$ sesame oil once daily for 5 days. Group 1 was the control group and was given the vehicle only. Groups 2,3, 4, 5 and 6 received $10 \mu \mathrm{g}$ or $\mathrm{E}_{2}-17 \beta, 10 \mu \mathrm{g}$ and $100 \mu \mathrm{g}$ of $\mathrm{E}_{2}-17 \alpha$, $100 \mu \mathrm{g}$ of $\mathrm{T}$ and $100 \mu \mathrm{g}$ of DHT respectively. Groups 7 and 8 received T $(100 \mu \mathrm{g})$ and DHT $(100 \mu \mathrm{g})$ respectively together with $\mathrm{E}_{2}-17 \beta(10 \mu \mathrm{g})$. All the mice were sacrified $24 \mathrm{hr}$ after the last injection and the back skin was removed and then the adhering tissue was cleaned off. The skin was minced, dehydrated, and 
defatted with several changes of acetone followed by $\mathrm{CHCl}_{3}-\mathrm{MeOH}(1: 1, \mathrm{v} / \mathrm{v})$ mixture. Approx. $100 \mathrm{mg}$ of the fat-free dried sample was mixed with $10 \mathrm{ml}$ of $0.05 \mathrm{M}$ Tris- $0.01 \mathrm{M} \mathrm{CaCl}_{2}$ buffer, $\mathrm{pH} 7.9$, containing $10 \mathrm{mg}$ of Pronase E. The sample was then incubated at $47^{\circ} \mathrm{C}$ for $24 \mathrm{hr}$ and another $10 \mathrm{mg}$ of the enzyme was added after adjustment of $\mathrm{pH}$, and the incubation was continued for another $24 \mathrm{hr}$. The digest was added with trichloroacetic acid to $10 \%$ concentration and the precipitated protein was centrifuged off. The supernatant was dialyzed against distilled water and evaporated in vacuo. The total hexosamine was determined by a modification of the Elson-Morgan procedure (Gatt and Berman, 1966). In order to determine HA, the crude GAG fraction was precipitated by adding cetylpyridinium chloride. The precipitate was dissolved in $4 \mathrm{M} \mathrm{NaCl}$ and reprecipi- tated with ethanol twice. HA in GAG obtained here was measured using Streptomyces hyaluronidase according to the method of Hatae and Makita (1975). Briefly, $25 \mu l$ of the aqueous crude GAG solution (up to $50 \mu \mathrm{g}$ of HA) and $50 \mu l$ of the enzyme (2 TRU) in $50 \mathrm{~mm}$ sodium acetate buffer, pH 5.0, were incubated at $60^{\circ} \mathrm{C}$ for $150 \mathrm{~min}$; the reaction mixtures were measured for $\mathrm{N}$-acetyl glucosamine by MorganElson reaction (Reissig et al., 1955).

\section{Results and Discussion}

The concentration of hexosamine in the pronase digests (total hexosamine), expressed

Table 1. Effects of gonadal hormones on total hexosamine content in male mouse skina

\begin{tabular}{clccc}
\hline \hline Group & Treatmentb & No. of Animals & Hexosamine Content & $\%$ of Control \\
\hline 1 & Control & 7 & $1.85 \pm 0.07$ & 100 \\
2 & $\mathrm{E}_{2}-17 \beta(10 \mu \mathrm{g})$ & 7 & $6.01 \pm 0.97 \mathrm{c}$ & 324 \\
3 & $\mathrm{E}_{2}-17 \alpha(10 \mu \mathrm{g})$ & 5 & $2.62 \pm 0.34 \mathrm{c}$ & 141 \\
4 & $\mathrm{E}_{2}-17 \alpha(100 \mu \mathrm{g})$ & 6 & $3.64 \pm 0.47 \mathrm{c}$ & 196 \\
5 & $\mathrm{~T}(100 \mu \mathrm{g})$ & 7 & $2.45 \pm 0.41 \mathrm{c}$ & 133 \\
6 & $\mathrm{DHT}(100 \mu \mathrm{g})$ & 7 & $1.92 \pm 0.31$ & 104 \\
7 & $\mathrm{E}_{2}-17 \beta(10 \mu \mathrm{g})+\mathrm{T}(100 \mu \mathrm{g})$ & 8 & $5.12 \pm 0.76 \mathrm{c}, \mathrm{e}$ & 277 \\
8 & $\mathrm{E}_{2}-17 \beta(10 \mu \mathrm{g})+\mathrm{DHT}(100 \mu \mathrm{g})$ & 8 & $5.08 \pm 0.76 \mathrm{c}, \mathrm{d}$ & 274 \\
\hline
\end{tabular}

a Values are expressed as $\mu$ mole $/ 100 \mathrm{mg}$ dry tissue and represents the mean \pm S.D.

b Animals were treated daily for 5 days with various doses of hormones in parentheses. $\mathrm{E}_{2}-17 \alpha$ : estradiol-17 $\alpha, \mathrm{E}_{2}-17 \beta$ : estradiol-17 $\beta, \mathrm{T}$ : testostosterone, DHT : $5 \alpha$-dihydrotestosterone.

c Significantly different from control (group 1), $\mathrm{p}<0.001$.

d Significantly different from $\mathrm{E}_{2}-17 \beta$ (group 2), $0.01>\mathrm{p}>0.001$.

e Significantly different from $\mathrm{E}_{2}-17 \beta$ (group 2 ), $0.05>\mathrm{p}>0.01$.

Table 2. Effect of gonadal hormones hormones on hyaluronic acid content in male mouse skina

\begin{tabular}{clccc}
\hline Group & Treatmentb & $\begin{array}{c}\text { No. of } \\
\text { Animals }\end{array}$ & $\begin{array}{c}\text { Hyaluronic Acid } \\
\text { Content }\end{array}$ & $\begin{array}{c}\% \text { of } \\
\text { Control }\end{array}$ \\
\hline 1 & Control & 7 & $199.5 \pm 17.5$ & 100 \\
2 & $\mathrm{E}_{2}-17 \beta(10 \mu \mathrm{g})$ & 7 & $1847.4 \pm 281.3 \mathrm{c}$ & 926 \\
3 & $\mathrm{E}_{2}-17 \alpha(10 \mu \mathrm{g})$ & 5 & $559.3 \pm 55.2 \mathrm{c}$ & 280 \\
4 & $\mathrm{E}_{2}-17 \alpha(100 \mu \mathrm{g})$ & 6 & $974.7 \pm 248.4 \mathrm{c}$ & 489 \\
5 & $\mathrm{~T}(100 \mu \mathrm{g})$ & 7 & $475.3 \pm 108.9 \mathrm{c}$ & 238 \\
6 & $\mathrm{DHT}(100 \mu \mathrm{g})$ & 7 & $221.0 \pm 78.9$ & 111 \\
7 & $\mathrm{E}_{2}-17 \beta(10 \mu \mathrm{g})+\mathrm{T}(100 \mu \mathrm{g})$ & 8 & $1387.8 \pm 307.6 \mathrm{c}, \mathrm{e}$ & 696 \\
8 & $\mathrm{E}_{2}-17 \beta(10 \mu \mathrm{g})+\mathrm{DHT}(100 \mu \mathrm{g})$ & 8 & $1296.5 \pm 290.1 \mathrm{c}, \mathrm{d}$ & 650 \\
\hline
\end{tabular}

a Values are expressed as $\mu \mathrm{g} / 100 \mathrm{mg}$ dry tissue and represents the mean \pm S.D.

b Animals were treated daily for 5 days with various doses of hormones in parentheses. $\mathrm{E}_{2}-17 \alpha$ : estradiol-17 $\alpha, \mathrm{E}_{2}-17 \beta$ : estradiol-17 $\beta, \mathrm{T}$ : testosterone, DHT : $5 \alpha$-dihydrotestosterone.

c Significantly different from control (group 1), $\mathrm{p}<0.001$.

d Significantly different from $\mathrm{E}_{2}-17 \beta$ (group 2), $0.01>\mathrm{p}>0.001$.

e Significantly different from $\mathrm{E}_{2}-17 \beta$ (group 2), $0.05>\mathrm{p}>0.01$. 
as $\mu$ mole of hexosamine per $100 \mathrm{mg}$ of dry tissue, is shown in Table 1. The total hexosamine contents of the hormone-treated groups except for the DHT-injected group were significantly higher than that of the control group.

It was further investigated whether these changes in the total hexosamine content depended on HA content. As shown in Table 2 , the response to various gonadal hormones was more marked in $\mathrm{HA}$ (expressed as $\mu \mathrm{g}$ of HA per $100 \mathrm{mg}$ of dry tissue) than in the total hexosamine.

Administration of $\mathrm{E}_{2}-17 \beta$ caused a large increment in both total hexosamine and HA contents in the male mouse skin, confirming earlier results (Grosman et al., 1971).

Also the injection of $\mathrm{E}_{2}-17 \alpha \quad(10$ and $100 \mu \mathrm{g})$ significantly increased in both total hexosamine and $\mathrm{HA}$ contents as $\mathrm{E}_{2}-17 \beta$ did. This result is very interesting, because $\mathrm{E}_{2}-17 \alpha$ is not thought to have biological activity in uterus (Jensen et al., 1966).

$\mathrm{T}$ produced a similar but less marked change in HA content compared with that by $E_{2}-17 \beta$. This demonstrates that $T$ did not exhibit the species specificity in HAincreasing action, since the same effect by $\mathrm{T}$ was already observed in the rabbit skin (Davidson and Small, 1963) and rat skin (Kofoed et al., 1970) in contrast to the result of $E_{2}-17 \beta$.

On the contrary, DHT showed only insignificant changes in this system, though DHT is known as the most potent androgen in many tissues. This is of interest in connection with the findings of other investigators which indicated the nuclear retention of $\mathrm{T}$, not DHT, in the mouse and rat kidney (Bullock et al., 1971; Ritzén et al., 1972).

$\mathrm{T}$ or DHT injected with $\mathrm{E}_{2}-17 \beta$ blocked the increase in both total hexosamine and HA contents produced by $\mathrm{E}_{2}-17 \beta$ alone in the male mouse skin. These data suggest that $T$ and DHT are antagonistic to $E_{2}-17 \beta$ in this tissue.

The mechanism and mode of action of these gonadal hormones including $\mathrm{E}_{2}-17 \beta$ involved in the HA increment are not known at present. Although Sasaki and Ketkar (1968) previously demonstrated that both $\mathrm{E}_{2}-17 \beta$ and $\mathrm{T}$ increased UDP-glucose dehydrogenase and L-glutemine-D-fructose-6phosphate aminotransferase activites in the male mouse skin, the specific enzyme for HA metabolism such as HA synthetase and hyaluronidase (under the influence of various gonadal hormones) should be investigated directly. It might be possible that the HA increment is caused by the general metabolic disturbances through the administration of $\mathrm{E}_{2}-17 \beta$ rather than by the direct action of $\mathrm{E}_{2}-17 \beta$, because we were unable to demonstrate the presence of a cytoplasmic receptor of $\mathrm{E}_{2}-17 \beta$ in the same tissue (Kanke et al., 1977).

\section{Acknowledgment}

The authors express their appreciation to Mr. Y. Kayanuma for his technical assistance.

\section{References}

Bullock, L. P., C. W. Bardin and S. Ohno (1971). Biochem. Biophys. Res. Commun. 44, 1537.

Davidson, E. A. and W. Small (1963). Biochim. Biophys. Acta 69, 453.

Gatt, R. and E. R. Berman (1966). Anal. Biochem. 15, 167.

Grosman, N., E. Hvidberg and J. Schou (1971). Acta Pharmacol. Toxicol. 30, 458.

Hansson, V., W. S. McLean, A. A. Smith, D. J. Tindall, S. C. Weddington, S. N. Nayfeh, F. S. French and E. M. Ritzén (1974). Steroids 23, 823.

Hatae, Y. and A. Makita (1975). Anal. Biochem. 64, 30 .

Jensen, E. V., H. I. Jacobson, J. W. Flesher, M. N. Saha, G. N. Gupta, S. Smith, V. Colueci, D. Shiplacoff, H. G. Neuman, E. R. DeSombre and P. W. Jungblut. Steroid Dynamics (edited by $\mathrm{T}$. Nakao, G. Pincus and J. W. Tait). Academic Press, New York, London, p. 133 (1966).

Kanke, Y., H. Nishina, Y. Mori and R. I. Bashy (1977). Acta Endocrinol. 85, 429.

Kofoed, J. A., C. E. Bozzini and A. A. Tocci (1970). ibid. 63, 193. 
Reissig, J. L., J. L. Strominger and L. F. Leloir (1955). Sasaki, S. and M. B. Ketker (1968). Experimentia J. Biol. Chem. 217, 959.

24, 128.

Ritzén, E. M., S. N. Nayfeh, F. S. French and P. A. Sobel, H., K. D. Lee and M. J. Hewlett (1965). Aronin (1972). Endocrinology 91, 116. Biochim. Biophys. Acta 101, 225. 